\title{
Growth Performance, Cecal Fermentation and Blood Biochemistry of Rabbits Fed Diet Supplemented with Urea - Bentonite Combination
}

\author{
M. A. Abdl-Rahman (Corresponding author) \\ Department of Physiology, Faculty of Veterinary Medicine, Cairo University, Egypt \\ Faculty of Veterinary Medicine, Cairo University, Giza-12211, Egypt \\ Tel: 202-2864-5669Ｅ-mail:mahmod.abdelhafez@gmail.com \\ Sohair Y. Saleh \\ Department of Physiology, Faculty of Veterinary Medicine, Cairo University, Egypt \\ Faculty of Veterinary Medicine, Cairo University, Giza-12211, Egypt \\ Tel: 202-3338-6209 E-mail: sohair_saleh@hotmail.com \\ A. Zaki Amal \\ Department of Biochemistry, Animal Health Research Institute, Dokki, Egypt \\ Tel: 105-759-949 E-mail: am_zaki35@yahoo.com \\ S. Abd El-Hamid Safaa \\ Department of Biochemistry, Animal Health Research Institute, Dokki, Egypt \\ Tel: 111-215-405 E-mail: safaa1962@hotmail.com
}

\begin{abstract}
Seventy six New Zealand white rabbits of about $700 \pm 80$ gm live weight were used to evaluate the influence of diet supplemented with urea-bentonite combination on cecal characteristics, metabolism and rabbit growth performance. The rabbits were assigned into four dietary treatments control, bentonite-supplemented (with $2.5 \%$ sodium bentonite), urea-supplemented (with $1 \%$ urea) and urea - bentonite co-supplemented ( $1 \%$ urea $+2.5 \%$ sodium bentonite). Co-supplementation decreased cecal $\mathrm{pH}$ value and ammonia nitrogen $\left(\mathrm{NH}_{3}-\mathrm{N}\right)$ concentration, increased total volatile fatty acids (VFAs) concentration, increased butyrate at the expence of acetate and propionate, increased fermentation efficieny and bacterial mass. Additionally, co-supplementation increased serum total proteins and glucose concentrations while no change was recorded in serum urea and creatinine concentrations. Serum levels of AST were decreased in all experimental groups in comparison with control group whereas, serum levels of ALT were increased only by addition of urea alone. Moreover, urea-bentonite combination achieved an improvement in live weight gain and feed conversion effeciency by about $32 \%$ and $33 \%$ respectively with reference to control and thus considered cost effective. The study indicates that, a low cost urea-bentonite combination can replace about $50 \%$ of protein content of the high cost conventional rabbit feed and additionally improve rabbit growth performance that would be a valuable feeding strategy in developing countries.
\end{abstract}

Keywords: Bentonite, Cecal Fermentation, Rabbit, Urea

\section{Introduction}

Feeding a traditional alfalfa and maize diet to rabbits is not likely to be desirable or economic in the future as resource depletion and competition between human and livestocks for grains forces up the price of grain (Preston, 2006). The efficient use of forage based diets by rabbits and their abundance in most developing countries encouraged their use instead of traditional rabbit feed. However, the moderate protein content of such feeds should be compensated through enhancing the production of cecotropes that contain approximately $28-30 \%$ crude protein $50 \%$ of which are bacterial cells (Stevens \& Hume, 1995). 
Several studies have shown that intake of low quality roughages is increased when supplements of non-protein nitrogen (NPN) are given (King, 1971; Raharjo et al., 1986; Singh et al., 1988 \& Oluokun, 2001). Rabbits are efficiently capable of utilizing urea as a nitrogen source because of the high urease activity in the caecum (Marounek et al., 1995). However, in the gut dietary urea is converted to ammonia that unless well utilized by ceacal microbes in microbial protein synthesis, it may be absorbed and this could result in toxicity (Cheeke, 1994). Furthermore, increased cecal ammonia levels, causes an increase in cecal $\mathrm{pH}$ that may allow pathogens to flourish and may increase the potential for enteritis (Cheeke, 1994).

Sodium bentonite is an expanded lattice clay of the montmorillonite group of minerals (Bates \& Jackson, 1980) with high ion exchange capacity that binds a wide range of cations (Fenn \& Leng, 1989). Because of its huge surface area and the negative charges on its surface, bentonite has a great ability to adsorb ammonia from a solution when ammonia concentration is high and to release it when the concentration falls (Ivan et al., 1992) therefore, its addition to rabbit diet can partly equalize the supply of nitrogen to cecal microbes.

This experiment was therefore, conducted to study whether provision of bentonite would improve urea utilization by cecal microbes and the impact of this coupled addition on rabbit growth performance.

\section{Materials and methods}

\subsection{Animals, diets and experimental design}

The animals were selected from a flock of rabbits raised in the rabbitry of Physiology department, Faculty of Veterinary Medicine, Cairo University. The experiment involved 76, forty day old, New Zealand white rabbits selected to constitute uniform live weight groups of about $700 \pm 80 \mathrm{gm}$ at the beginning of the experiment. The rabbits were randomly assigned into four dietary treatments each of 19 animals (composition and chemical analysis of formulated diets are shown in Table 1). Diets were designated as control, urea-supplemented (with $1 \%$ urea), bentonite-supplemented (with $2.5 \%$ sodium bentonite) and urea - bentonite co-supplemented (1\% urea $+2.5 \%$ sodium bentonite). The supplements were well mixed with their corresponding diets before pelleting and the animals were adapted for gradual levels of both supplements for one week until reaching to the desired level prior to the onset of the experiment. Rabbits received their corresponding diets ad libitum and the experiment lasted for 45 days during which fresh, clean water was available at all times.

\subsection{Data collection}

Rabbits were weighed individually when the experiment started, then once weekly and at the end of the experiment. The feed intake was estimated for group housing (total feed consumption of group/number of alive animals) because rabbits are highly social and group rearing is advised in commercial farms. Feed conversion efficiency (gm body gain/100 gm feed intake) were then precisely calculated on an individual basis. Growth data of ill and dead rabbits were excluded from the analysis. Morbidity (corresponded to frequency of enteric disease or severe loss of weight) and mortality rates were also recorded.

\subsection{Sampling procedures}

At the end of the experiment, ten rabbits from each group were used for collection of blood samples by venipuncture. Blood samples were collected into clean, centrifuge tubes and centrifuged at 5,000 x $g$ for 10 minutes. Sera were separated and kept at $-20{ }^{\circ} \mathrm{C}$ until assayed for determination of serum urea, creatinine, total proteins, glucose, and the activities of aspartate aminotransferase and alanine aminotransferase. Thereafter, five rabbits from each group were slaughtered by severing the jugular vein, the carcasses were subsequently opened, the ceca were removed and their contents were squeezed out into beakers. Immediately cecal contents were used for measuring $\mathrm{pH}$ values by electronic digital $\mathrm{pH}$ meter. For determination of total volatile fatty acids (VFAs) concentrations and individual VFAs proportions, $5 \mathrm{~mL}$ of $5 \%$ orthophosphoric acid were added to $5 \mathrm{~mL}$ of cecal contents. For determination of ammonia nitrogen $\left(\mathrm{NH}_{3}-\mathrm{N}\right)$ concentration, $2 \mathrm{~mL}$ of cecal content were acidified with $2 \mathrm{~mL}$ of $0.2 \mathrm{M}$ hydrochloric acid solution. Both samples were then stored at $-20^{\circ} \mathrm{C}$ until analysed. For determination of bacterial mass, the remaining cecal conents were mixed with the buffer solution of Goering \& Van Soest (1970) in the proportion 1:1 (v/v) and then were squeezed through six layers of sterile gauze to obtain the bacterial suspension. Immediately, $2.8 \mathrm{ml}$ formol-saline $(0.8 \% \mathrm{NaCl}$ in $36.5 \%$ formaldhyde $)$ were added to $10 \mathrm{ml}$ bacterial suspension to quickly inhibit bacterial growth.

\subsection{Analytical Procedures for Samples of Cecal Digesta}

Cecal $\mathrm{NH}_{3}-\mathrm{N}$ concentrations were measured by spectrophotometry according to Chaney \& Marbach (1962). Bacterial mass was determined using the membrane filter procedures of Isaacson et al (1975). Total VFAs concentrations were measured by steam distillation according to Eadie et al. (1967). The molar proportions of VFAs were analyzed using high performance liquid chromatography (HPLC; Model Water 600; UV detector, 
Millipore Crop.) according to the method of Mathew et al. (1997). After the results of VFAs molar proportions had been received, the fermentation efficiencies (FE) were calculated on the basis of the equation worked out by Orskov (1975) and modified by Baran \& Zitnan (2002):

$\mathrm{FE}=(0.622 \mathrm{a}+1.092 \mathrm{p}+1.56 \mathrm{~b}) 100 /(\mathrm{a}+\mathrm{p}+2 \mathrm{~b})$

where: $a, p$ and $b$ express the concentrations $\left(\mathrm{mmol} \cdot \mathrm{l}^{-1}\right)$ of acetic, propionic and butyric acids respectively in the total concentration of VFAs produced. The final result of this equation is expressed in percentage and shows an amount of energy stored in VFAs as a percentage participation of the initial energy.

\subsection{Statistical analysis}

Data were analyzed by one way analysis of variance (ANOVA) test according to Snedecor \& Cochran (1980). Treatment means were compared by the least significance difference (LSD) at $5 \%$ level of probability.

\section{Results and discussion}

Nutritional factors act on cecal ecosystem at two levels: by supplying appropriate quantity and quality of nutrients to the flora, and ensuring good physico-chemical conditions for cecal microbes (Gidenne, 2006). Adding urea to rabbit feed provide adequate levels of ammonia in the cecum for continuous growth of cecal microbes. However, numerous studies have demonstrated that urea supply is useless, because increased cecal ammonia level may predisposes to enteritis or result in toxicity if absorbed (Cheeke, 1994). In this study, we added sodium bentonite in combination with urea to alleviate the previously mentioned constraint.

\subsection{Cecal fermentation traits}

From data presented in "Table 2" it is clear that, the concentrations of cecal VFAs were increased in all experimental groups in comparison with control group that points to greater cecal microbial activity. According to Garcia et al. (2002), VFAs concentrations could reach a value of up to $99.8 \mathrm{mmol} \cdot \mathrm{l}^{-1}$, depending on rabbit's age and physiological status as well as food ingredients. When absorbed, VFAs produced in the cecum can cover about $40 \%$ of rabbit maintenance requirement (Marty \& Vernay 1984) so, higher VFAs production could be beneficial with regard to better energy supply and better body weight gain as a consequence. Additionally, VFA provide the main metabolic fuel for the mucosa of the large intestine (Roediger, 1986). The recorded increase in butyrate at the expense of acetate and propionate associated with addition of bentonite in combination with urea could be due to domination of butyrate producing bacteria (Vernay \& Marty, 1984). Conversely, the high yield of acetate at the expense of propionate and butyrate accompanying addition of urea alone could be the end result of enhanced acetogenesis. Reductive acetogenesis (microbial synthesis of acetate from $\mathrm{CO}_{2}$ and $\mathrm{H}_{2}$ ) is a feature of rabbit cecal fermentation which, with age, is partly replaced with methanogenesis (Piattoni et al., 1996). Decreased molar proportions of branched chain VFAs in all experimental groups with reference to control reveals reduced microbial deaminative activity as deamination of branched chain amino acids represents the major source of branched chain VFAs (Hino \& Russell, 1985). Ivan et al (1992) speculated that, bentonite could absorb some proportions of proteolytic enzymes, which would then be unable to act on the dietary proteins or it could adsorb free dietary amino acids that also would not be accessible to bacterial deamination. Concerning $\mathrm{NH}_{3}-\mathrm{N}$ concentration, it was decreased by addition of bentonite alone or in combination with urea while it was increased by addition of urea alone with reference to control. The tendency to lower $\mathrm{NH}_{3}-\mathrm{N}$ concentrations could be attributed either to a greater ammonia utilization by cecal microbes or to the great ability of bentonite to adsorb ammonia when present at high concentrations (Saleh, 1994). Increased $\mathrm{NH}_{3}-\mathrm{N}$ concentration by addition of urea alone could be attributed to production of surplus amount of $\mathrm{NH}_{3}-\mathrm{N}$ via highly active ureolytic cecal microbes (Marounek et al., 1995). The cecal pH value did not alter by addition of bentonite alone or in combination with urea while it was increased by addition of urea alone with reference to control. The $\mathrm{pH}$ value of rabbit cecal chyme shows a falling tendency when VFAs concentrations grows and ammonia concentration falls (Garcia et al., 2002), and hence, increased cecal $\mathrm{pH}$ associated with addition of urea alone is mostly due to excessive ammonia production. Nevertheless, lack of alteration in cecal $\mathrm{pH}$ value in case of urea-bentonite combination is doubtlessly related to improvements in cecal physico-chemical conditions when bentonite was added. Regarding bacterial mass, it was increased by addition of bentonite alone or in combination with urea and was not affected by addition of urea alone. However, the value for co-addition was higher than that for bentonite alone by about $32.6 \%$ and higher than that for control by about $56.7 \%$. Increased bacterial mass by addition of urea-bentonite combination points to a synchronous supply of energy and $\mathrm{NH}_{3}-\mathrm{N}$ in the cecum for continuous growth of cecal microbes. This may be related to increased VFAs concentration and/or increased butyrate associated with this treatment. Huber \& Herrara (1994) suggested that a synchronous supply of energy and $\mathrm{NH}_{3}-\mathrm{N}$ is required for ammonia utilization in microbial protein synthesis. Microbial cells use the ATP generated in the formation of VFAs to provide the energy for protein synthesis and according to Isaacson et al. (1975), the 
moles of ATP generated per mole of VFA end-products are 2 for acetate, 3 for butyrate and 3 for propionate. Addition of bentonite alone or in combination with urea was associated with improved fermentation efficiency, whereas, urea alone exerted a declining effect. The recorded increase in fermentation efficiency achieved by addition of bentonite alone or in combination with urea is actually the end result of its ability to increase butyrate at the expense of acetate and propionate. In contrast, addition of urea alone exerted a declining effect on fermentation efficiency by modifying cecal VFAs profile in the direction of increased acetate. Calculation of fermentation efficiency is based on convertion of hexose energy to VFAs energy on the basis of equations worked out by Orskov (1975) and modified by Baran \& Zitnan (2002).

\subsection{Blood biochemical parameters}

Data presented in table (3) identify that, serum urea and creatinine concentrations were increased by addition of urea alone while were not affected by addition of bentonite alone or in combination with urea with regards to control. Serum urea concentration is a good indicator of protein and energy status of the animal as well as liver and kidney functions. A considerable portion of blood urea originates from deamination of amino acids caused by a glucose or energy deficit (Abdelgadier et al., 1996). Therefore, the recorded values for serum urea concentration reveals that animals received urea-bentonite combination were in a better metabolic state than those received urea alone. It appears that bentonite prevented excessive ammonia absorption and alleviated the burden of hepatic detoxification of ammonia into urea. Various estimates for the energy cost of ureagenesis assumed a stoichiometry of 4 ATP per mole of urea (Summers et al., 1988). The cost of ureagenesis in rat liver was calculated to account for 8 to $12 \%$ of total hepatic ATP use (McBride \& Kelly, 1990). Lack of increase in creatinine level by addition of urea-bentonite combination indicates that damage to the kidney didn't occur (Silanikove et al., 1996). Serum glucose concentration was decreased by addition of urea alone with regards to control. Elliot (1980) suggested that, dietary changes greatly affect glucose production by gluconeogenesis in the liver via their effects on propionyl co.A carboxylase activity, an enzyme essential in the biochemical pathway through which propionate is normally incorporated in the tricarboxylic acid cycle. Decreased serum glucose by addition of urea alone could be attributed to inhibition of hepatic gluconeogenetic activity. Leonard et al (1977) suggested that, hepatic detoxification of ammonia into urea could reduce plasma glucose level possibly by its direct inhibitory effect on liver gluconeogenetic activity through a competition for ATP by increased activity of urea cycle. In contrast, addition of bentonite alone or in combination with urea was associated with increased serum glucose concentration indicating that addition of bentonite probably improved hepatic gluconeogenetic activity. Moreover, addition of bentonite alone or in combination with urea was associated with increased cecal butyrate concentration. Butyrate is the basic metabolic fuel in the large intestine tissues of the rabbit and it also serves as an activator of hepatic gluconeogenesis (Remesy et al., 1995). Thus, increased cecal butyrate concentration could increase the absorption of glucose precursors and /or enhance hepatic gluconeogenesis. Serum total protein concentrations were decreased by addition of urea alone whereas, were increased by addition of urea-bentonite combination with reference to control. Plasma proteins are mainly synthesized in the liver and their values in rabbits supplemented with urea-bentonite combination indicate that these animals were in a good nutritional status and their livers had no pathological lesions. Amino acids are sources of metabolic energy as well as being the building units of proteins and their use by the animal for protein synthesis take place only if the energy needs are met. Therefore, decreased serum total protein concentrations by addition of urea alone points to an energy deficit in this group probably resulting from the energy cost of hepatic detoxification of ammonia into urea. Serum levels of AST were decreased in all experimental groups in comparison with control group whereas, serum levels of ALT were increased only by addition of urea alone and were not affected by addition of bentonite alone or in combination with urea. Serum levels of ALT and AST are conventionally used for diagnosing domestic animals hepatic damage (Silanikove \& Timokin, 1992). Changes in these enzymes were found when feed-related hepatotoxicity occurred (Silanikove et al., 1996). Prolonged feeding of $0.5 \%$ urea in the diet of rabbits resulted in liver and kidney lesions (Cheeke, 1994). The recorded values of the two enzymes suggest that no damage to the liver had occurred by addition of urea-bentonite combination.

\subsection{Growth performance, morbidity and mortality rates}

As shown in table 4 , the average daily gain $(\mathrm{g} / \mathrm{d})$ and feed conversion efficiency varied significantly with reference to control, recording the lowest value for addition of urea alone and the highest value for addition of urea-bentonite combination. The later treatment achieved an improvement in live weight gain and feed conversion effeciency by about $32 \%$ and $33 \%$ respectively with regards to control. It appears that urea-bentonite combination improved ammonia utilization by cecal microbes that was reflected positively on rabbit protein status directly and on rabbit energy status indirectly through reduced ureagenesis that costs about $10 \%$ of total energy expenditure. Moreover, it didn't cause any deleterious effects on liver and kidney functions as indicated 
from the blood biochemical parameters. Furthermore, sodium bentonite has the ability to expand 10-15 times its size when water is added (Bringe \& Shultz. 1969) and this probably created more bulk in the cecum, reduced the rate of feed passage, and thus increased feed efficiency. The morbidity rate observed by addition of bentonite alone or in combination with urea was the same like that observed in control group (one rabbit /group that corresponds to $5.26 \%$ ) while it was increased to seven rabbits by adding urea alone that corresponds to $36.84 \%$. Likewise, the morality rate monitored by addition of bentonite alone or in combination with urea was identical to that recorded in the control group (one rabbit /group that corresponds to 5.26\%) while it was increased to four rabbits by adding urea alone that corresponds to $21.05 \%$. It appears that addition of bentonite was effective in adjusting the $\mathrm{pH}$ value of rabbit cecum and consequently preventing the growth of pathogenic bacteria. Additionally bentonite adsorbed ammonia released via ureolytic cecal activity and prevented excessive ammonia absorption and toxicity.

\subsection{Cost effectiveness}

Data in table 5 show that, prices for adding $1 \%$ urea and $2.5 \%$ bentonite are 0.05 and 0.02 L.E. $/ \mathrm{kg}$ rabbit diet respectively totaling approximately 0.07 L.E. $/ \mathrm{kg}$ rabbit diet. The price of $7.6 \%$ soyabean meal that was removed and replaced by this treatment is 0.2 L.E. $/ \mathrm{kg}$ rabbit diet. This implies that using this treatment could save about $0.13 \mathrm{~L} . \mathrm{E} / \mathrm{kg}$ rabbit diet. Therefore the total feeding cost decreased by addition of urea alone or in combination with bentonite in comparison with control diet. However, the relative profit was increased by $55.5 \%$ in case of urea - bentonite combination while it was decreased by $25.2 \%$ in case of adding urea alone. It is obvious that this was related to increased average meat yield/rabbit suggesting an improvement of feed conversion efficiency in case of urea - bentonite combination.

\section{Conclusion}

Adding $2.5 \%$ bentonite together with $1 \%$ urea to rabbit feeds can save about $50 \%$ of protein content of the high cost conventional rabbit feeds and in the same time improves rabbit growth performance via improving ammonia utilization by cecal microbes without causing any deleterious effects on liver and kidney functions. Thus, addition of such combination to rabbit feeds is considered cost effective and would be a valuable feeding strategy in developing countries.

\section{References}

Abdelgadier, I. E., Morril, J. L., \& Higgins, J. J. (1996). Ruminal availabilities of protein and starch: Effect on growth and ruminal plasma metabolites of dairy calves. Journal of Dairy Science, 79, 283.

Baran, M., \& Zitnan, R. (2002). Effect of monensin sodium on fermentation efficiency in sheep rumen. Arch. Tierzucht, 45, 181-185.

Bates, R. L., \& Jackson, J. A. (1980). Glossary of Geology. American Geological Institute, Alexandria, VA 22302.

Bringe, J. D., \& Shultz, L. H. (1969). Effect of roughage type on added bentonite in maintaining fat test. Journal of Dairy Science, 52, 465-471.

Chaney, A. L., \& Marbach, E. P. (1962). Modified reagents for determination of urea and ammonia. Clinical Chemistry, 8, 130-132

Cheeke, P. R. (1994). Nutrition and Nutritional Diseases. In: Manning, PJ, Ringler, DH \& CE Newcomer (eds) The Biology of the Laboratory Rabbit. Academic Press, New York. 2nd ed. p 321.

Eadie, J. M., Hobson, P. N., \& Mann, S. O. (1967). A note on some comparisons between the rumen content of barley fed steers and that of young calves also fed on high concentrate rations. Animal production, 9, 247-250.

Elliot, J. M. (1980). Propionate metabolism and vitamin $\mathrm{B}_{12}$. In: Ruckebusch Y, Thivend P. (eds): Digestive Physiology and Metabolism in Ruminants. Avi publishing comp, USA. 485-503.

Fenn, P. D., \& Leng, R. A. (1989). Wool growth and sulfur amino acid entry rate in sheep fed roughage based diets supplemented with bentonite and sulfur amino acids. Australian Journal of Agriculutre Research, 40, 889-896.

Garcia, J., Gidenne, T., Falcao-e-Cunha, L., De Blas, C. (2002). Identification of the main factors that influence caecal fermentation traits in growing rabbits. Animal Research, 51, 165-173.

Gidenne, T. (2006). The caecal ecosystem in the growing rabbit: impact of nutritional and feeding factors. $3 r d$ American Rabbit Congress, Maringa, Brasil. 
Goering, H. K., \& Van Soest, P. J. (1970). Forage Fiber Analysis. Agricultural Handbook no. 379. Washington, DC: Agricultural Research Service, US Department of Agriculture.

Hino, T., \& Russell, J. B. (1985). Effect of reducing - equivalent disposal and NADH/NAD on deamination of amino acids by intact rumen microorganisms and their cell extract. Applied Environmental Microbiology, 50, 1368-1374.

Huber, J. T. \& Herrara, R. (1994). Synchrony of protein and energy supply to enhance fermentation. In: Asplund, J. M., (ed), Principles of protein nutrition of ruminants. Columbia, USA, pp. 113-136.

Isaacson, H. R., Hinds, F. C., Bryant, M. P., \& Owens, F. N. (1975). Efficiency of energy utilization by mixed rumen bacteria in continuous culture. Journal of Dairy Science, 58, 1645-1659.

Ivan, M., Dayrel, M. S., Mahadevan, S., Hidiroglou, M. (1992). Effects of Bentonite on Wool Growth and Nitrogen Metabolism in Fauna-Free and Faunated Sheep. Journal of Animal Science, 70, 3194.

King, J. O. L. (1971). Urea as a protein supplement for growing rabbits. British Vet. J., 127, 523-528.

Leonard, M. C., Buttery, P. J., \& Lewis, D. (1977). The effects on glucose metabolism of feeding a high-urea diet to sheep. British Journal of Nutrition, 38, 455-462.

Marounek, M.,Vovk, S. J. \& Skfiivanova, V. (1995). Distribution of activity of hydrolytic enzymes in the digestive tract of rabbits. British Journal of Nutrition, 73, 463-469

Marty, J., \& Vernay, M. (1984). Adsorption and metabolism of the volatile fatty acids in the hindgut of the rabbit. British Journal of Nutrition, 51, 265-277

Mathew, S., Sagathevan, S., Thomas, J., \& Mathen, G. (1997). An HPLC method for estimation of volatile fatty acids in ruminal fluid. Indian Journal of Animal Sciences, 67, 805- 807.

McBride, B. W., \& Kelly J. W. (1990). Energy cost of absorption and metabolism in the ruminant gastrointestinal tract and liver: a review. Journal of Animal Science, 68, 2997-3010.

Oluokun, J. A. (2001). Performance of growing rabbits fed a low protein diet supplemented with urea or roasted soybean meal. J. Animal Prod. Res. 17, 89-99

Orskov, E. R. (1975). Manipulation of rumen fermentation for maximum food utilization. World Reveiw Nutrition Diet, 22, 153-182.

Piattoni, F., Demeyer, D., \& Martens, L. (1996). In vitro study of the age-dependent cecal fermentation pattern and methanogenesis in young rabbits. Reproduction and Nutrition Development, 36, 253-261.

Preston, T. R. (2006). Forages as protein sources for pigs in the tropics. Workshop-seminar "Forages for Pigs and Rabbits" MEKARN-CelAgrid, Phnom Penh, Cambodia, 22-24 August, 2006. [Online] Available: http://www.mekarn.org/proprf/preston.htm

Raharjo, V. C., Cheeke, P. R., \& Patton, N. M. (1986). Growth and reproductive performance of rabbits on a moderately low crude protein diet with or without methionine or urea supplementation. Journal of Animal Science, 63, 795-8032 Dept. of Anita. Sci.

Remesy, C., Demigne, C., Morand, C. (1995). Metabolism of short-chain fatty acids in the liver. In: Cummings JH, Rombeau JL, Sakata T (eds): Physiological and Clinical Aspects of Short-chain fatty acids. Cambridge University Press, London. 171-190.

Roediger, W. E. (1986). Interrelationship between bacteria and mucosa of the gastrointestinal tract. In: Hill, MJ (ed.): Bacterial metabolism in the digestive tract. CRC Press, Boca Raton, 202-209

Saleh, M. S. (1994). Using of feed additives for feeding farm animals. Ph.D. Thesis, Fac. of Agric. Kafr El-Sheikh, Tanta University, Egypt.

Silanikove, N., Gilboa, N., Perevolotsky, A. \& Nitsan, Z. (1996). Goat fed tannin-containing leaves do not exhibit toxic syndromes. Small Ruminant Researsh, 21, 195.

Silanikove, N., \& Tiomokin, D. (1992). Toxicity induced by poultry litter consumption: Effect on parameters reflecting liver function in beef cows. Animal production, 54, 203.

Singh, B., Makkar H. P., \& Lal Krishna, L. (1988). Utilization by growing rabbits of a low crude protein diet with or without urea and groundnut cake supplementation. J. Appl. Rabbit Res. 1, 25-29.

Snedecor, G. W., \& Cochran, W. G. (1980). Statistical methods. Oxford and J.B.H.puplishing com. 7th edition. 
Stevens, C. E. \& Hume, I. D. (1995). Comparative Physiology of the Vertebrate Digestive System. Cambridge University Press, United Kingdom. 2nd ed..

Summers, M., B. W. McBride, B. W., \& Milligan, L. P. (1988). Components of basal energy expenditure. In: A. Dobson \& M. J. Dobson (eds.): Aspects of Digestive Physiology in Ruminants. Cornell University Press, Ithaca, NY. 257-286.

Vernay, M., \& Marty, J. (1984). Absorption and metabolism of butyric acid in rabbit hind-gut. Comp. Biochem. Physiol. 77, 89.

Table 1. Ingredients and chemical composition of the experimental diets

\begin{tabular}{|l|l|l|l|l|}
\hline Item & \multicolumn{4}{l|}{ Experimental diets } \\
\hline Ingredients, \% & control & $1 \%$ urea & $\begin{array}{l}2.5 \% \\
\text { bentonite }\end{array}$ & $\begin{array}{l}1 \% \text { urea } \\
2.5 \% \text { bentonite }\end{array}$ \\
\hline Yellow corn & & & 30.00 & 29.00 \\
\hline Berseem hay & 30.00 & 29.00 & 41.80 & 45.00 \\
\hline Wheat bran & 41.80 & 45.00 & 10.00 & 10.00 \\
\hline Soybean meal & 10.00 & 10.00 & 12.60 & 5.00 \\
\hline molasses & 12.60 & 5.00 & 5.00 & 5.00 \\
\hline Lin seed oil & 5.00 & 5.00 & 0.00 & 1.30 \\
\hline Urea & 0.00 & 1.30 & 0.00 & 1.00 \\
\hline Sodium bentonite & 0.00 & 1.00 & 2.50 & 2.50 \\
\hline Dicalcium phosphate & 0.00 & 0.00 & 0.60 & 0.60 \\
\hline Trace mineral salt & 0.60 & 0.60 & 0.10 & 0.10 \\
\hline Vitamin and mineral premix & 0.10 & 0.10 & 0.30 & 0.30 \\
\hline DL-Methionine & 0.30 & 0.30 & 0.30 & 0.30 \\
\hline Chemical analysis $(\%$ of dry matter) & 0.30 & & \\
\hline Crude fiber & 0.30 & 13.80 & 13.80 & 13.80 \\
\hline Crude protein & 13.80 & 16.42 & 16.42 & 16.42 \\
\hline Ether extract & 16.42 & 3.00 & 3.00 & 3.00 \\
\hline Nitrogen free extract & 3.00 & 56.25 & 56.25 & 56.25 \\
\hline Calcium & 56.25 & 0.74 & 0.74 & 0.74 \\
\hline Phosphorus & 0.74 & 0.49 & 0.49 & 0.49 \\
\hline Digestible energy (MJ/ kg) & 9.30 & 9.30 & 9.30 & 9.30 \\
\hline
\end{tabular}

Table 2. Effect of urea and/or Bentonite supplementations on cecal metabolites

\begin{tabular}{|c|c|c|c|c|}
\hline \multirow[t]{2}{*}{ Parameters } & \multicolumn{4}{|c|}{ Experimental diets } \\
\hline & control & $1 \%$ urea & $2.5 \%$ bentonite & $\begin{array}{l}1 \% \text { urea }+2.5 \% \\
\text { bentonite }\end{array}$ \\
\hline $\mathrm{P}^{\mathrm{H}}$ value & $5.86^{\mathrm{a}} \pm 0.07$ & $6.32^{b} \pm 0.06$ & $5.74^{\mathrm{a}} \pm 0.05$ & $5.68^{\mathrm{a}} \pm 0.08$ \\
\hline Total VFAs $\left(\mathrm{mmol} \cdot \mathrm{l}^{-1}\right)$ & $82.1^{\mathrm{a}} \pm 0.47$ & $84.0^{b} \pm 0.37$ & $84.4^{\mathrm{b}} \pm 0.74$ & $84.7^{b} \pm 0.22$ \\
\hline Acetic acid (mol.\%) & $73.46^{\mathrm{a}} \pm 0.26$ & $77.66^{\mathrm{b}} \pm 0.42$ & $70.04^{c} \pm 0.34$ & $69.66^{\mathrm{c}} \pm 0.48$ \\
\hline Propionic acid (mol.\%) & $7.72^{\mathrm{a}} \pm 0.24$ & $7.34^{\mathrm{a}} \pm 0.21$ & $6.22^{b} \pm 0.15$ & $6.34^{\mathrm{b}} \pm 0.24$ \\
\hline Butyric acid (mol.\%) & $13.94^{\mathrm{a}} \pm 0.11$ & $12.30^{\mathrm{b}} \pm 0.30$ & $20.40^{c} \pm 0.57$ & $20.46^{\mathrm{c}} \pm 0.43$ \\
\hline BCVFA* (mol.\%) & $4.88^{\mathrm{a}} \pm 0.11$ & $3.10^{b} \pm 0.25$ & $3.34^{\mathrm{b}} \pm 0.21$ & $3.54^{\mathrm{b}} \pm 0.14$ \\
\hline $\mathrm{NH}_{3}-\mathrm{N}\left(\mathrm{mmol} \cdot \mathrm{l}^{-1}\right)$ & $15.74^{\mathrm{a}} \pm 0.27$ & $18.66^{\mathrm{b}} \pm 0.40$ & $12.66^{\mathrm{c}} \pm 0.33$ & $12.82^{\mathrm{c}} \pm 0.49$ \\
\hline bacterial dry weight & $31.08^{\mathrm{a}} \pm 0.9$ & $28.94^{\mathrm{a}} \pm 0.6$ & $34.20^{\mathrm{b}} \pm 1.2$ & $45.36^{\mathrm{c}} \pm 1.0$ \\
\hline fermentation efficiency (\%) & $69.50^{\mathrm{a}} \pm 0.09$ & $68.78^{b} \pm 0.12$ & $70.20^{c} \pm 0.05$ & $70.26^{c} \pm 0.13$ \\
\hline
\end{tabular}

$B C V F A^{*}$ branched chain VFA

Data presented as means $\pm S E, N=5$

Values having different letters in the same raw are significantly different at $P<0.05$ 
Table 3. Effect of urea and/or Bentonite supplementations on on some related metabolic parameters

\begin{tabular}{|l|l|l|l|l|}
\hline Parameters & \multicolumn{4}{l|}{ Experimental diets } \\
\cline { 2 - 5 } & control & $1 \%$ urea & $2.5 \%$ bentonite & $\begin{array}{l}1 \% \text { urea }+2.5 \% \\
\text { bentonite }\end{array}$ \\
\hline Urea $\left(\mathrm{mmol} \cdot 1^{-1}\right)$ & $2.19^{\mathrm{a}} \pm 0.01$ & $4.78^{\mathrm{b}} \pm 0.08$ & $2.12^{\mathrm{a}} \pm 0.07$ & $2.17^{\mathrm{a}} \pm 0.08$ \\
\hline Creatinine $\left(\mathrm{mmol} \cdot \cdot^{-1}\right)$ & $85.3^{\mathrm{a}} \pm 0.9$ & $209.5^{\mathrm{b}} \pm 6.0$ & $84.1^{\mathrm{a}} \pm 3.2$ & $90.9^{\mathrm{a}} \pm 2.8$ \\
\hline Glucose $\left(\mathrm{mmol} \cdot \mathrm{l}^{-1}\right)$ & $4.05^{\mathrm{a}} \pm 0.13$ & $3.80^{\mathrm{b}} \pm 0.08$ & $4.59^{\mathrm{c}} \pm 0.07$ & $5.53^{\mathrm{d}} \pm 0.06$ \\
\hline Total proteins $\left(\mathrm{mol} \cdot \mathrm{l}^{-1}\right)$ & $68.14^{\mathrm{a}} \pm 1.18$ & $54.66^{\mathrm{b}} \pm 0.75$ & $68.07^{\mathrm{a}} \pm 1.40$ & $75.36^{\mathrm{c}} \pm 0.99$ \\
\hline AST $\left(\mathrm{u} \cdot \mathrm{l}^{-1}\right)$ & $16.16^{\mathrm{a}} \pm 0.47$ & $13.76^{\mathrm{b}} \pm 1.24$ & $14.66^{\mathrm{b}} \pm 0.33$ & $14.13^{\mathrm{b}} \pm 0.66$ \\
\hline ALT $\left(\mathrm{u} \cdot \mathrm{l}^{-1}\right)$ & $10.65^{\mathrm{a}} \pm 0.38$ & $13.5^{\mathrm{b}} \pm 0.73$ & $10.14^{\mathrm{a}} \pm 0.40$ & $11.34^{\mathrm{a}} \pm 0.27$ \\
\hline
\end{tabular}

Data presented as means $\pm S E, N=10$

Values having different letters in the same raw are significantly different at $P \varangle 0.05$

Table 4. Effect of urea and/or Bentonite supplementations on growth performance, morbidity and mortality rates

\begin{tabular}{|l|l|l|l|l|}
\hline \multirow{2}{*}{ Parameters } & Experimental diets & \multicolumn{3}{l|}{} \\
\cline { 2 - 5 } & control & $1 \%$ urea & $2.5 \%$ bentonite & $\begin{array}{l}1 \% \text { urea }+2.5 \% \\
\text { bentonite }\end{array}$ \\
\hline Average daily gain (g/d) & $15.70^{\mathrm{a}} \pm 1.12$ & $12.92^{\mathrm{a}} \pm 1.06$ & $18.81^{\mathrm{a}} \pm 2.46$ & $20.88^{\mathrm{b}} \pm 1.45$ \\
\hline Feed conversion effeciency & $19.28^{\mathrm{a}} \pm 1.37$ & $16.23^{\mathrm{a}} \pm 1.40$ & $19.28^{\mathrm{a}} \pm 2.40$ & $25.65^{\mathrm{b}} \pm 1.78$ \\
\hline Morbidity (\%) & 5.26 & 36.84 & 5.26 & 5.26 \\
\hline Mortality (\%) & 5.26 & 21.05 & 5.26 & 5.26 \\
\hline
\end{tabular}

Data presented as means $\pm S E, N=19$

Values having different letters in the same raw are significantly different at $P<0.05$

Table 5. Effect of experimental diets on relative profits of growing New Zealand rabbits

\begin{tabular}{|l|l|l|l|l|}
\hline \multirow{2}{*}{ Parameters } & \multicolumn{4}{|l|}{ Experimental diets } \\
\cline { 2 - 5 } & Control & $1 \%$ urea & $\begin{array}{l}2.5 \% \\
\text { bentonite }\end{array}$ & $\begin{array}{l}1 \% \text { urea+ } \\
\text { bentonite }\end{array}$ \\
\hline Price / kg diet (L.E.) & 1.70 & 1.55 & 1.72 & 1.57 \\
\hline Average feed intake (kg/ rabbit) & 3.66 & 3.68 & 4.49 & 3.63 \\
\hline Average feeding cost / rabbit (L.E.) & 6.22 & 5.70 & 7.72 & 5.70 \\
\hline Average meat yield in kg / rabbit & 0.706 & 0.581 & 0.846 & 0.939 \\
\hline Selling price/ rabbit (L.E.)* & 17.65 & 14.25 & 21.15 & 23.47 \\
\hline Net profits (L.E.)** & 11.43 & 8.55 & 13.43 & 17.77 \\
\hline Relative profits (\%) & 100.0 & 74.8 & 117.5 & 155.5 \\
\hline
\end{tabular}

* Selling price of $1 \mathrm{~kg}=25$ L.E.

** Net profit $=$ selling price of meat yield - feed cost. 